\title{
PENDIDIKAN KARAKTER BERBASIS KEARIFAN LOKAL (STUDI DI JEMBRANA BALI)
}

\author{
Saihu ${ }^{1}$ \\ ${ }^{1}$ Dosen Pascasarjana Institut PTIQ Jakarta \\ made_syaikhu@yahoo.com
}

Received: 14/01/2019, Accepted: 20/02/2019, Published: 25/02/2019

\begin{abstract}
ABTRACT
This paper discusses the ethnopedagogy-based education model in Jembrana Bali. The paper focuses on exploring the impact of ethnopedagogy-based education on the process of interaction and integration that leads to peaceful practices in Hindu and Muslim communities in Jembrana. Data sources are obtained through unstructured observation and interviews during 2017 to 2018. The writing uses the mosaic analogy theory proposed by Issac Baer Bekson (1891-1975) and peace education proposed by John Dewey (1859-1952). Writing shows that through an ethnopedagogy-based education process can shape the character of Hindus and Muslims in Jembrana to be humanistic, tolerant and inclusive. This paper also shows that to shape the character and character of Hindus and Muslims in Jembrana as well as to foster diversity understanding, is through a male tradition, thus the interaction of Hindu and Muslim communities in Jembrana leads to the process of association, integration, complementation and sublimation.
\end{abstract}

Keywords: education, ethnopedology, male, association, integration, complementation, sublimation.

\begin{abstract}
ABSTRAK
Tulisan ini membahas tentang model pendidikan berbasis ethnopedagogy di Jembrana Bali. Tulisan berfokus menelusuri dampak dari pendidikan berbasis ethnopedagogy terhadap proses interaksi dan integrasi yang mengarah pada praktik damai pada masyarakat Hindu dan Muslim di Jembrana. Sumber data diperoleh melalui observasi dan wawancara tidak terstruktur selama 2017 sampai dengan 2018. Tulisan menggunakan teori mosaic analogy yang dikemukakan oleh Issac Baer Bekson (1891-1975) dan peace education yang dikemukakan oleh John Dewey (1859-1952). Tulisan memperlihatkan bahwa melalui proses pendidikan berbasis ethnopedagogy dapat membentuk karakter masyarakat Hindu dan Muslim di Jembrana menjadi humanis, toleran, dan inklusif. Tulisan ini juga memperlihatkan bahwa untuk membentuk karakter dan watak masyarakat Hindu dan Muslim di Jembrana serta untuk menumbuhkembangkan pemahaman kebhinekaan, adalah melalui tradisi male, dengan demikian interaksi masyarakat Hindu dan Muslim di Jembrana mengarah pada proses asosiasi, integrasi, komplementasi, dan sublimasi.
\end{abstract}




\section{Pendidikan Karakter Berbasis...}

\section{A. PENDAHULUAN}

Tulisan membahas tentang bagaimana kerja dari model pendidikan berbasis ethnopedagogy (kearifan lokal) dalam membentuk karakter toleran dan humanis antar dua komunitas, yaitu Hindu dan Muslim di Jembrana Bali. Karena kearifan lokal yang ada di masyarakat dapat dijadikan sebagai mekanisme sosio-kultural yang diyakini dan telah terbukti sebagai sarana yang ampuh menggalang persaudaraan dan solidaritas antar warga yang telah melembaga dan mengkristal dalam tatanan sosial dan budaya. ${ }^{1}$

Pendidikan berbasis etnopedagogy (kearifan lokal) adalah sebuah praktik pendidikan dimana pengetahuan dihasilkan, disimpan, diterapkan, dan diwariskan melalui sarana kearifan lokal pada suatu daerah. ${ }^{2}$ Lebih jauh, kearifan lokal (lokal wisdom) berarti; pandangan hidup, ilmu pengetahuan, dan berbagai strategi kehidupan yang berwujud aktivitas, dilakukan oleh masyarakat setempat untuk menjawab berbagai masalah dalam pemenuhan kebutuhan mereka.

Kendati demikian, masih banyak ditemukan pandangan yang mengecilkan

\footnotetext{
1 Azyumardi Azra. (2002). Reposisi Hubungan Agama dan Negara: Merajut Kerukunan Antarumat. Jakarta: Kompas, hlm. 209.

${ }^{2}$ Chaedar Alwasilah. (2009). Etnopedagogi Landasan Praktik Pendidikan dan Pendidikan Guru. Bandung: PT Kiblat Buku Utama, hlm. 51.
}

arti dan peran serta kearifan lokal dalam menciptakan toleransi antar komunitas yang berbeda. Salah satunya adalah pandangan yang dikemukakan oleh kelompok-kelompok puritan seperti Salafi Wahabi yang dalam dakwahnya selalu ingin memurnikan ajaran Islam.

Masyarakat Muslim yang menjadikan kearifan lokal sebagai sarana untuk berinteraksi dengan komunitas yang berbeda agama dan budaya sering disebut sebagai kelompok sinkretis yang menggabungkan ajaran agama Islam dengan kepercayaan lain atau sebagai masyarakat yang belum menjalankan syariat Islam secara kaffah. Penghargaan mereka terhadap lingkungan alamnya disalah pahami sebagai bentuk paham yang dipengaruhi oleh animism atau sebagai perbuatan syirik yang dilarang agama. ${ }^{34}$

Bagi masyarakat Hindu dan Muslim di Jembrana, model pendidikan berbasis kearifan lokal atau etnopedagogi, bertujuan untuk membantu dan atau menciptakan generasi dalam mengembangkan semua unsur potensi pribadinya, baik itu intelektualitas, spiritualitas, moralitas, sosialitas, maupun rasionalitas, serta dapat

\footnotetext{
${ }^{3}$ F. Nasir, N. (1999). Integrasi dan Konflik dalam Adat Pertanian Masyarakat Aceh (I). Bandung: Gunung Djati Press, hlm. 82.

${ }^{3}$ Wawancara dengan Asmari, tanggal 7 April 2018.
} 
menguatkan solidaritas antar umat beragama, sekaligus menjawab model pendidikan yang terlalu berorientasi ke Barat yang pada praktiknya banyak menghilangkan nilai-nilai keunggulan budaya, agama, serta kearifan lokal yang ada di masyarakat. ${ }^{5}$

Model pendidikan seperti ini dimulai dari lingkungan keluarga dengan banyak menanamkan konsep-konsep, gagasan, dan nilai-nilai, serta pandangan hidup masyarakat Jembrana yang tertuang dalam filosofi Tri Hita Karana (tiga penyebab kesejahteraan) meliputi: Parahyangan (menjalin hubungan baik dengan Tuhan), Pawongan (menjalin hubungan baik dengan sesama manusia), dan Palemahan (menjalin hubungan baik dengan alam semesta). Pandangan hidup ini diajarkan kepada seluruh anggota keluarga yang pada tataran selanjutnya masing-masing dari mereka akan saling mengoreksi satu sama lain, apabila ada dari anggota keluarga yang tidak melaksanakan filosofi hidup tersebut. ${ }^{6}$

Begitu penting dan strategisnya nilai kearifan lokal dalam pembangunan bangsa, maka sangat wajar bila pendidikan karakter memfokuskan kajiannya pada penggalian nilai-nilai kearifan lokal (etnopedagogi)

6 W. A. Surasmi. (2012). Menggugah Kesadaran Guru dalam Kearifan Lokal pada Era Globalisasi. Surabaya. hlm. 8. yang hidup di dalam masyarakat dan budaya Indonesia yang ber-bhinneka tunggal ika. ${ }^{7}$

Karena sebagaimana diketahui, bahwa tradisi dan budaya yang terdapat dalam kearifan lokal, berperan penting dalam pengembangan kepribadian generasi muda yang dalam setiap tradisi tersebut terdapat nilai-nilai perenial yang unggul.

\section{B. TINJAUAN PUSTAKA}

Pada hakikatnya belajar adalah suatu interaksi antara individu dan lingkungan. Lingkungan menyediakan rangsangan (stimulus) terhadap individu dan sebaliknya individu memberikan respons terhadap lingkungan. Dalam proses interaksi itu dapat terjadi perubahan pada diri individu berupa perubahan karakter, dapat juga menyebabkan terjadinya perubahan lingkungan, baik positif atau negatif. Hal ini menunjukkan bahwa fungsi lingkungan merupakan faktor yang penting dalam proses pendidikan terlebih lagi pendidikan karakter.

Menurut Thomas Lickona, yang dimaksud dengan pendidikan karakter adalah suatu usaha yang disengaja untuk membantu seseorang sehingga ia dapat memahami, memperhatikan, dan

Azyumardi Azra. (2003). Pendidikan Multikultural: Membangun Kembali Indonesia Bhinneka Tunggal Ika. Jakarta: Republika, hlm. 9. 


\section{Pendidikan Karakter Berbasis...}

melakukan nilai-nilai etika yang inti. ${ }^{8}$ Berdasarkan definisi ini, maka jenis karakter yang ingin ditanamkan kepada setiap individu adalah menumbuhkembangkan kembali, memperhatikan secara lebih mendalam nilai-nilai yang ada dalam satu masyarakat melalui jalur pendidikan atau dengan narasi yang sedikit berbeda, mereka memiliki kesadaran untuk membiasakan diri melakukan nilai-nilai tersebut.

Pengertian yang disampaikan Lickona di atas menunjukkan adanya proses perkembangan kejiwaan yang melibatkan pengetahuan (moral knowing), perasaan (moral feeling), dan tindakan (moral action), sekaligus juga memberikan dasar yang kuat untuk membangun pendidikan karakter yang koheren dan komprehensif. Pengertian ini juga menekankan bahwa pendidikan harusnya "memaksa" para setiap individu untuk melakukan kegiatan-kegiatan yang dapat membimbing mereka untuk berpikir kritis mengenai persoalanpersoalan etika dan moral; menginspirasi mereka untuk setia dan loyal dengan tindakan-tindakan etika dan moral; dan memberikan kesempatan kepada mereka untuk mempraktikkan perilaku etika dan moral tersebut.

8 Thomas Lickona. (1991). Educating for Character: How Our School Can Teach Respect and Responsibility. New York: Bantam Books, hlm. 9.
Terkait dengan persoalan diatas, tulisan membahas eksistensi tradisi male sebagai sebuah model ethnopedology (pendidikan berbasis kearifan lokal) yang dijadikan pandangan hidup masyarakat Jembrana dalam membentuk karakter masyarakatnya yang untuk konteks Bali sangat majemuk. Tulisan ini menggunakan teori mosaic analogy yang dikemukakan oleh Isaac Baer Berkson (1891-1975) yang berpandangan bahwa masyarakat yang terdiri dari individuindividu yang beragam latar belakang agama, budaya, etnis, bahasa, memiliki hak untuk mengekspresikan identitas budayanya secara demokratis sehingga dari proses tersebut akan memunculkan keunikan tersendiri dari adanya dialektika antar tradisi dari komunitas yang berbeda. ${ }^{9}$ Dengan demikian, maka akan terbentuklah sebuah kelompok masyarakat yang berkarakter inklusif, humanis, dan pluralis sehingga dapat menerima segala macam perbedaan di dalam kelompoknya tersebut.

Teori ini sama sekali tidak meminggirkan identitas budaya tertentu termasuk identitas budaya minoritas sekalipun. Maka untuk konteks Jembrana, teori ini dipandang tepat dalam memotret kemajemukan yang ada di daerah ini. Umat

${ }^{9}$ Horace M. Kallen. (1924). Cultures and Democracy in the United Stated. New York: Boni \& Liveright, hlm. 56. 
beragama (Hindu, Islam, Budha, Kristen, dan Katolik) dapat mengekspresikan identitas keagamaannya masing-masing dengan tenang, meskipun penduduknya mayoritas beragama Hindu. Kebersamaan ini selanjutnya dapat membentuk suatu ikatan quotidian yang kuat, yaitu itu sebuah ikatan sederhana yang bersifat rutin tetapi tidak terkoordinasi secara organis sebagai lawan dari ikatan asotional. Seperti; saling mengunjungi antara satu warga dengan warga lain, sering makan bersama, pergi ke pesta bersama, serta membiarkan anak-anak bermain dengan etnis lain. ${ }^{10}$

Untuk memperkuat aspek pendidikan, selain menggunakan teori mosaic analogy, tulisan ini juga menggunakan teori peace education yang didasarkan pada aliran pendidikan progressivisme yang dipelopori oleh John Dewey (1859-1952). Menurut Dewey, belajar adalah pengalaman nyata dari lapangan. ${ }^{11}$ Dewey, berargumen bahwa pendidikan merupakan transaksi antara person dengan lingkungannya. ${ }^{12}$ Atau

10 Ashutosh Varshney. (2002). Ethnic Conflict and civic life: Hindu and Muslim in India. New Haven and London: Yale University Press, hlm. 11.

11 Anna Stetsenko. (2011). From relational ontology to transformative activist stance on development and learning: expanding Vygotsky's (CHAT) project. Springer, 6 (7), hlm. 471-491.

12 Saifullah Idris. (2014). Demokrasi dan Filsafat Pendidikan. Banda Aceh: Ar Raniry Press, hlm. 42. dengan kata lain, pembelajaran berpusat pada peserta didik yang memiliki variasi proses dan pengalaman belajar di setiap sarana atau lembaga pendidikan. ${ }^{13}$

Selain itu, Dewey, memandang individu sebagai sesuatu yang fungsional dalam hidup sosial. Setiap individu dalam pandangan progresivisme adalah organisme yang mengalami satu proses pengalaman. Sebab setiap individu merupakan bagian integral dari lingkungan, peristiwa-peristiwa yang terjadi di masyarakat, interaksi sosial, perasaan, pikiran dan benda-benda di sekitarnya. ${ }^{14}$ Jika lingkungan belajar itu damai, menyenangkan, penuh toleransi, maka kondisi tersebut berdampak pada pengalaman belajar dan kondisi kejiwaan yang didapat oleh setiap individu.

Peace education, sebagai sebuah teori pendidikan, mempromosikan pengetahuan, keahlian-keahlian, sikap dan nilai-nilai yang diperlukan untuk membawa perubahan karakter setiap individu. ${ }^{15}$ Dalam implementasinya, peace education menghubungkan kecerdasan intelektual "supra-rasional" dan kesadaran spiritual "supra-religius" yang dalam konteks

13 Keiran Egan. (2002). Getting it Wrong from the Beginning Our Progressivist Inheritance from Herbert Spancer, John Dewey, and Jean Peaget. Binghamtom: Vail Ballou, hlm. 68.

${ }^{14}$ Muhammad Nur Syam. (1984). Filsafat Pendidikan dan Dasar Filsafat Pendidikan Pancasila. Surabaya: Usaha Nasional, hlm. 250.

${ }^{15}$ Moh. Toriqul Chaer. (2016). Islam dan Pendidikan Cinta Damai. ISTAWA, 2 (1), 73-94. 


\section{Pendidikan Karakter Berbasis...}

Jembrana kedua kecerdasan tersebut terdapat pada kearifan lokal (tradisi male) yang dapat menggugah dimensi psikologis dan sosiologis setiap individu. Melalui model pendidikan ethnopedagogy setiap individu akan mencapai puncak daya kreativitasnya melalui nafsu dan insting mereka. Sehingga dalam interaksinya mereka dapat melakukan pencegahan (to prevent) konflik dan kekerasan; menyelesaikan (to resolve) konflik secara damai; dan menciptakan (to create) kondisi yang kondusif. ${ }^{16}$

Pendekatan peace education (pendidikan damai) dapat menjadi strategi dalam rangka proses deradikalisasi umat beragama. Sebab dalam pendidikan damai, memberikan pandangan, wawasan dan keterbukaan kepada peserta didik terkait dengan realita pluralitas umat manusia baik dari segi suku, agama, budaya, ras, bahasa, dan lain-lain. Keragaman yang ada bukanlah hal yang harus ditolak, tetapi dikelola dan disyukuri sebagai kekayaan dan potensi yang memberikan berkah kehidupan umat. Oleh karena itu, bagi Dewey, aspek-aspek yang harus dikembangkan dan diajarkan dalam pendidikan adalah perdamaian dan anti kekerasan (peace and non-violence), hak

16 R. Ridwan Hasan Saputra. (2016). Berfikir Supra Rasional. Jakarta: Republika, hlm. 72. asasi manusia (human rights), demokrasi (democracy), toleransi (tolerance), pemahaman antar bangsa dan antar budaya (international and intercultural understanding), serta pemahaman perbedaan budaya dan bahasa (cultural and linguistic diversity). ${ }^{17}$

Teori pendidikan semacam ini memberikan pemahaman serta penanaman karakter kepada setiap individu akan pentingnya sikap "toleransi aktif" dalam kehidupan umat yang sangat beragam. Sikap "toleransi aktif" dalam konteks ini bukan berarti hanya sekadar membiarkan orang lain ada, tetapi juga bagaimana mengembangkan kebersamaan dan saling pengertian. Dengan begitu maka toleransi menjadi sarana minimal atau modal dasar bagi terwujudnya hubungan antar umat beragama yang saling menghormati dan menyadari. Maka secara otomatis sikapsikap radikal yang mengarah kepada konflik umat beragama satu terhadap umat agama lain dapat di eliminasi.

\section{METODOLOGI}

Penelitian ini adalah penelitian lapangan (field research), yang sering digunakan secara bersamaan dengan studi etnografi, ${ }^{18}$ yaitu bersifat eksploratif

${ }^{17}$ Imam Machali. (2013). Peace Education dan Deradikalisasi Agama. Jurnal Pendidikan Islam, 2 (1), hlm. 41-64.

${ }^{18}$ Kennet D. Bailey. (1982). Methods of 
yang bertujuan untuk memperoleh gambaran tentang pelaksanaan aktivitas tradisi male sebagai sarana pendidikan informal yang teraktualisasi dengan baik dalam aktivitas kehidupan sehingga dapat menanamkan karakter inklusif pada masyarakat Jembrana sehingga tercipta kerukunan antar umat beragama khususnya umat Hindu dan Muslim. Penelitian ini dimulai dari bulan Maret sampai dengan Juli 2018 di wilayah Kabupaten Jembrana Provinsi Bali yang secara spesifik penelitian ini memfokuskan observasinya pada bagaimana dimensi humanis, pluralis, dan toleran teraktualisasi dalam aktivitas tradisi male sebagai sarana untuk memperkokoh hubungan yang harmonis antara kedua umat beragama.

Untuk tujuan ini, maka penelitian ini lebih tepat menggunakan pendekatan kualitatif. Sebab dalam penelitian kualitatif, peneliti mengkaji sesuatu dalam setting natural dan menafsirkan fenomena terkait dengan makna. Penelitian kualitatif sebagaimana yang dikatakan oleh Sharan B. Merriam, memiliki empat karakteristik utama yaitu: 1) menekankan pada proses, pemahaman, dan makna; 2) peneliti berfungsi sebagai instrumen utama dalam pengumpulan dan analisis data; 3) proses

Social Research. New York: A Division of Macmillan Publishing Co. Inc, hlm. 254. bersifat induktif; dan 4) hasilnya bersifat deskripsi yang kaya. ${ }^{19}$

Berbeda dengan penelitian kuantitatif yang mengambil jarak antara peneliti dengan subjek penelitian, penelitian kualitatif menyatu dengan situasi objek yang diteliti (personally involved with research participants, to the points of sharing perspective). ${ }^{20}$ Selain itu, Lincoln dan Guba mengidentifikasi beberapa perbedaan aksioma pada penelitian kualitatif yang relevan dengan penelitian ini meliputi:

1. Sifat Realitas

Penelitian kualitatif berlandaskan pada filsafat post-positivisme atau paradigma interpretive. Yaitu suatu realitas atau objek tidak dapat dilihat secara parsial dan dipecah ke dalam beberapa variabel. Penelitian kualitatif memandang objek sebagai sesuatu yang dinamis, hasil konstruksi pemikiran dan interpretasi terhadap gejala yang diamati, serta utuh (holistic) karena setiap aspek dari objek itu mempunyai suatu kesatuan yang tidak dapat dipisahkan.

2. Hubungan Peneliti dengan Yang Diteliti

${ }^{19}$ Sharan B. Merriam. (2009). Qualitative Research: A Guide to Design and Implementation. (USA). The Jossey-Bass, hlm. 13-14.

20 Gall D Meredith and other. (2003). Educational Research: An Introduction, 7th eds. Boston: Pearson Education, Inc. hlm. 25. 


\section{Pendidikan Karakter Berbasis...}

Dalam penelitian kualitatif, peneliti berfungsi sebagai human instrument melalui teknik pengumpulan data participant observation (observasi berperan serta) dan juga in depth interview (wawancara mendalam), maka peneliti harus berinteraksi dengan sumber data. Dengan demikian peneliti kualitatif mengenal betul orang yang memberikan data.

\section{Hubungan Antar}

Dalam penelitian kualitatif yang bersifat holistik dan lebih menekankan pada proses, maka penelitian kualitatif dalam melihat hubungan antar variabel pada objek yang diteliti lebih bersifat interaktif yaitu saling mempengaruhi (reciprocal/ interaktif).

\section{Kemungkinan Generalisasi}

Penelitian kualitatif tidak melakukan generalisasi, tetapi lebih menekankan kedalaman informasi sehingga sampai pada tingkat makna. Walaupun penelitian kualitatif tidak membuat generalisasi, tidak berarti hasil penelitian kualitatif tidak dapat diterapkan di tempat lain. Generalisasi dalam penelitian kualitatif disebut dengan transferability (keteralihan). Maksudnya adalah bahwa, hasil penelitian kualitatif dapat ditransferkan atau diterapkan di tempat lain, manakala kondisi tempat lain tersebut tidak jauh berbeda dengan tempat penelitian. $^{21}$

\footnotetext{
${ }^{21}$ Lincon Yvonna S. Guba and Egon G.
}

Adapun metode yang digunakan dalam penelitian ini adalah metode studi kasus. Sebagai salah satu varian dalam penelitian kualitatif, studi kasus memberikan uraian dan penjelasan komprehensif mengenai suatu setting tertentu, dokumen, atau suatu kejadian tertentu. $^{22}$ Dengan mempelajari secara maksimal mengenai hal ini, peneliti ingin mendapatkan pandangan yang lengkap dan mendalam mengenai aktualisasi tradisi Male di Jembrana. Kelebihan dari metode studi kasus sebagaimana diungkapkan oleh Lincoln dan Guba, adalah berikut:

a. Studi kasus merupakan sarana utama bagi peneliti emik, yakni menyajikan pandangan subjek yang di teliti;

b. Studi kasus menyajikan uraian menyeluruh pada apa yang dialami dalam kehidupan sehari-hari;

c. Studi kasus merupakan sarana efektif untuk menunjukkan hubungan antara peneliti dan responden;

d. Studi kasus memungkinkan untuk menemukan konsistensi internal yang tidak merupakan konsistensi gaya dan konsistensi faktual, tetapi juga keterpercayaan (trustworthiness);

(1985). Naturalistic Inquiry. Newbury Park: SAGE, hlm. 37.

${ }^{22}$ Robert Bogdan Biklen dan Sari Knopp. (1998). Qualitative Research for Education: An Introduction to Theory and Methods. Boston: Allyn and Bacon, hlm. 54. 
e. Studi kasus terbuka bagi penilaian atas konteks yang turut berperan bagi pemaknaan dalam konteks tersebut. $^{23}$

Selanjutnya teknik pengumpulan data dalam penelitian ini dilakukan dengan cara observasi, in-depth interview, dan dokumentasi dari dua komunitas yaitu Hindu dan Muslim. Observasi, yaitu: mengamati secara langsung aktivitas tradisi male sebagai proses pendidikan informal dan interaksi antara komunitas Hindu dan Muslim di wilayah Jembrana. Observasi ini diarahkan untuk memahami setting of education serta kondisi sosial masyarakatnya. Begitu juga dengan memahami kondisi sosiologis masyarakat sebagai wadah pendidikan karakter terjadi di tengah masyarakat, serta memahami kemungkinan-kemungkinan terjadinya konflik sosial yang bisa jadi disebabkan oleh pemahaman teologis yang berbeda di Jembrana.

Teknik selanjutnya adalah wawancara mendalam (in-depth interview). Melalui teknik ini, banyak hal yang diperoleh dari informan. Teknik wawancara tak terstruktur merupakan teknik wawancara yang dipilih dalam penelitian ini. Teknik pengumpulan data

${ }^{23}$ Lincon Yvonna S. Guba and Egon G. (1985). Naturalistic Inquiry, hlm. 356. dengan wawancara tak terstruktur. Menurut Deddy Mulyana, dengan menggunakan teknik wawancara tak terstruktur, memungkinkan informan dapat mendefinisikan diri dan lingkungannya dengan menggunakan istilahnya sendiri yang tentu saja berdasarkan kultur dan tradisi yang mereka anut. $^{24}$

Dalam menganalisis data, penelitian ini mengacu pada prosedur analisis data Milles dan Hubermen. Menurut Milles dan Hubermen, analisis data dalam penelitian kualitatif, secara umum dimulai sejak pengumpulan data, reduksi data, penyajian data, dan penarikan kesimpulan atau verifikasi. Unsur-unsur metodologi dalam prosedur ini sekaligus mencerminkan komponen-komponen analisis yang bersifat interaktif. ${ }^{25}$ Kegiatan analisis selama pengumpulan data dimaksud untuk menetapkan fokus di lapangan, menyusun temuan sementara, pembuatan rencana pengumpulan data berikutnya, pengembangan pernyataan-pernyataan analitis dan penetapan sasaran-sasaran data berikutnya. Kemudian dari

${ }^{24}$ Dedi Mulyana. (2002). Metodologi Penelitian Kualitatif: Paradigma Baru Ilmu Komunikasi dan Ilmu Sosial Lainnya. Bandung: Remaja Rosdakarya, hlm. 183.

${ }^{25}$ Milles M. Hubermen and dan Michael. (1992). Analisis data Kualitatif. Jakarta: Universitas Indonesia, hlm. 92. 


\section{Pendidikan Karakter Berbasis...}

pengumpulan data (data collection) tersebut, direduksi (data reduction) sebagai upaya pemilihan pemusatan perhatian pada penyederhanaan, dan meng-abstrakkan data-data lapangan.

Dalam proses reduksi data, peneliti melakukan pemilihan atau pemetaan dengan membuat kategori-kategori berdasarkan permasalahan yang diteliti. Setelah hasil dari seperangkat reduksi, maka langkah selanjutnya adalah, menyajikan sekumpulan informasi atau data yang disusun, kemungkinan adanya penarikan kesimpulan. Kesimpulankesimpulan juga di verifikasi selama kegiatan penelitian berlangsung di lapangan, sehingga akan jelas bagaimana karakteristik data tersebut secara valid.

\section{PEMBAHASAN}

\section{Potret Kehidupan Beragama Hindu dan Muslim di Jembrana}

Dari 321.008 Jiwa penduduk Jembrana, 231.707 atau sekitar $72.18 \%$ beragama Hindu, kemudian disusul umat Islam dengan jumlah penduduk 81.329 jiwa atau $25.34 \%$, menyusul ketiga umat Kristen yang berjumlah 4.090 jiwa atau $1.27 \%$, lalu Katolik berjumlah 2.786 jiwa atau $0.87 \%$ Budha 1.069 jiwa, atau $0.33 \%$ Konghucu 15 jiwa, atau $0.00 \%$ dan aliran kepercayaan 12 jiwa atau
$0.00 \% .{ }^{26}$ Dari data-data tersebut, terlihat Jelas bahwa umat Hindu adalah umat yang mayoritas menjadi penduduk Jembrana kemudian disusul oleh umat Muslim.

Relasi harmonis antara kedua umat beragama ini (Hindu dan Muslim) banyak dipengaruhi oleh sejarah awal kedatangan umat Muslim di Jembrana. Menurut Dhurorudin Mashad, cikal bakal komunitas Muslim di Jembrana ternyata sudah sangat tua usianya. Dia membagi penyebaran masuknya Islam di wilayah Jembrana ke dalam dua tempat dan waktu, yaitu: Pertama, komunitas Muslim kuno di Desa Baluk. Eksistensi muslim di Jembrana sudah ada menyusul runtuhnya Kerajaan Majapahit oleh penyerangan Demak Islam pada tahun 1518. Seiring dengan peristiwa itu, pelan tapi pasti, beberapa kerajaan vassal Majapahit semakin banyak yang mendeklarasikan diri sebagai penganut Islam. Akibat realitas yang menggejala tersebut, para Raja Majapahit terkonversi menjadi Muslim terutama di tanah Jawa. Sementara para tokoh agama, pejabat negara, dan atau pangeran yang tidak mau menerima Islam, memilih mengungsi ke berbagai wilayah lain di Nusantara.

\footnotetext{
${ }^{26}$ Data BPS Kabupaten Jembrana Tahun 2015.
} 
Seiring dengan proses Islamisasi di tanah Jawa, Roro Anteng dan Joko Seger dengan para pengikutnya, mengungsi ke lereng Gunung Bromo, sehingga anak keturunan mereka kini lebih dikenal sebagai suku Tengger (singkatan dari kata gabungan Anteng dan Seger). Namun jumlah yang lebih banyak justru memilih meninggalkan Jawa menuju Bali, termasuk diantaranya Pangeran Wilis dan Pangeran Sepuh asal Blambangan. Peristiwa pengungsian Pangeran Wilis dan Pangeran Sepuh inilah yang ternyata justru dan sekaligus menjadi pangkal eksistensi komunitas Muslim di daerah Jembrana.

Mengungsinya kedua pangeran ini ditemani oleh kerabat dan para pengikutnya yang berjumlah \pm 40 orang. Sesampainya di Bali, kedua pangeran ini datang ke Pura Jati dengan membawa patung sakti sebagai oleh-oleh untuk Raja Jembrana. Kedua pangeran kemudian melanjutkan perjalanan untuk menghadap Raja Mengwi, karena Kerajaan Jembrana saat itu memang berada dibawah kedaulatan Kerajaan Mengwi. Sebelum berangkat, keduanya diiringkan raja bersama seorang abdi dekat raja bernama Pan Tabah yang ditugaskan untuk terus mendampingi pangeran. Kepada kedua pangeran itu, Raja Jembrana berpesan agar segera melapor bila sampai di Mengwi dan apabila mengalami masalah.
Ternyata, sesampainya kedua pangeran tersebut di Kerajaan Mengwi, mereka ditangkap, bahkan Pangeran Sepuh dibunuh. Sementara Pangeran Wilis dan Pan Tabah berhasil lolos dan kembali ke Kerajaan Jembrana.

Pangeran Wilis hendak pulang ke Jawa tetapi tidak diperkenankan oleh keluarga kerajaan. Kelurga Kerajaan Jembrana menghadiahkan sebidang tanah di Desa Banyubiru (sekarang Baluk) di bawah pohon beringin yang besar. Lalu di lokasi inilah Pangeran Wilis dan pengikutnya membangun pemukiman dan untuk memudahkan persembahyangan, Pangerang Willis membangun sebuah pura yang selanjutnya pura tersebut dikenal dengan nama Pura Majapahit.

Hal yang cukup unik di sini adalah bahwa di antara pengikut setia Pangeran Wilis, ternyata ada yang sudah memeluk agama Islam sejak dari Jawa. Meski berbeda agama, tetapi abdi yang beragama Islam tersebut tetap setia mendampingi tuannya. Walhasil, untuk menghormati pengiring setianya itu, Pangeran Willis mendirikan juga sebuah masjid di sebelah barat pura dengan nama Masjid Majapahit. Dan mereka itulah yang selanjutnya menjadi cikal bakal komunitas Muslim di Desa Baluk. $^{27}$

${ }^{27}$ Dhurorudin Mashad. (2014). Muslim Bali: 


\section{Pendidikan Karakter Berbasis...}

Melihat adanya perbedaan keyakinan diantara para pengikutnya, maka Pangeran Wilis membuat perjanjian tentang toleransi antar umat beragama di lokasi barunya itu. Untuk menghormati umat Islam, dalam setiap persembahyangan di pura, tidak perkenankan menggunakan sarana babi untuk hidangan dan cukup diganti dengan itik. Aturan ini terus diikuti secara turun menurun dan hingga kini. Bahkan tidak ada yang berani untuk melanggarnya. Sampai sebelum tahun 1965, komunitas Muslim di sekitar Pura Majapahit, ikut bergabung dalam upacara di pura meskipun sekadar untuk penghormatan. Agar keberadaannya tidak menganggur dan bengong (melamun), umat Islam dilibatkan untuk mekidung, yaitu kidung rengganis (dari Jawa), sedangkan umat Hindu mekidung mergasari. Namun seiring dengan bertambahnya kesadaran akan purifikasi Islam termasuk pada komunitas Muslim Banyubiru, maka komunitas Muslim tidak lagi terlibat dalam persembahyangan, akan tetapi tetap terlibat dalam pengamanan dan persiapan kegiatan upacara di pura. ${ }^{28}$

Kedua, Komunitas Muslim kampung kuno Loloan dan Air Kuning. Komunitas

Mencari Kembali Harmoni yang hilang. Jakarta: Pustaka Al-Kautsar, hlm. 151.

${ }^{28}$ Wawancara dengan Ida Bagus Komang Santika Putra, tanggal 7 April 2018.
Loloan. ini merupakan keturunan dari suku Bugis-Makasar dan Melayu (Kuala Trengganu) yang sudah beberapa abad lalu bermigrasi ke Bali. ${ }^{29}$ Keberadaan komunitas Muslim ini juga merupakan bukti historis, bahwa Islam sudah lama masuk di wilayah Jembrana dengan mempertahankan agama Islam dan adatistiadat Bugis serta Melayu. Asal-usul dari komunitas Muslim Loloan dan Air Kuning di Jembrana adalah orang-orang yang ber-etnis Bugis. Mereka datang dalam dua tahap, Pertama, tahun 1653-1655; Kedua, tahun 1660-1661 menyusul berakhirnya perang Makasar antara kerajaan Gowa melawan VOC yang di pimpin oleh Daeng Marewa. Suku Bugis-Makasar ini umumnya merupakan pelarian setelah adanya perjanjian bongaya pada saat Kerajaan Gowa kalah perang dengan Belanda.

Menurut KH. Ahmad Damanhuri, pelarian asal Sulawesi Selatan itu memang terus dikejar-kejar serdadu VOC (armada Speelman) dan armada Arung Palaka, karena sebagian perahu sisa eskadron Bugis-Makassar, masih memiliki senjata meriam. Kala itu, VOC kepada masyarakat sengaja membangun image negatif, bahwa kaum pelarian itu

29 Asep Saefullah dan M. Adib Misbahul Islam. (2009). Beberapa Aspek Kodikologi Naskah Keagamaan Islam di Bali. Lektur Keagamaan, 7 (1), hlm. 53-90. 
adalah perompak, karena mereka memang kerap melakukan serangan terhadap kapal-kapal VOC. Bahkan setelah Makasar jatuh di tahun 1667, Belanda membuat sayembara, bahwa Belanda akan memberikan hadiah sebesar 10.000-ringgit bagi siapa saja yang dapat menangkap eskadron (perahuperahu) keturunan Sultan Gowa (berjumlah 4 buah) yang disebut Iinun alias perompak. ${ }^{30}$

Pada Tahun 1669, Daeng Nahcoda dan pengikutnya mendarat di Air Kuning lalu memasuki Kuala Perancak serta tinggal untuk sementara waktu di lokasi yang disebut Kampung Bali. Peninggalannya sampai kini masih ada, berupa sumur yang jernih yang oleh warga disebut sumur bajo. Akhirnya mereka diberi izin oleh Raja Jembrana, yakni marga Arya Pancoran (Gusti Ngurah Pancoran) untuk menetap. Tempat mereka itu kini dikenal sebagai pelabuhan Bandar Pancoran (pelabuhan lama di Loloan Barat).

Eksistensi kaum pengungsi ini pada kenyataannya tidak menjadi beban bagi warga Jembrana, justru menjadi berkah. Banyak di antara kaum Bugis ini menjadi kekuatan keamanan utama (prajurit), serta berhasil membangun perekonomian

30 Ahmad Damanhuri. (1995). Sekilas Pandang Perkembangan Umat Islam di Kabupaten Dati II Jembrana. Jembrana, hlm. 20. baru berupa pelabuhan. Berkat perahuperahu pedagang jelmaan eskadron keturunan Sultan Gowa tersebut, Jembrana akhirnya menjadi wilayah yang tidak lagi terisolir dari dunia luar. Realitas ini menyebabkan hubungan antara kaum Bugis-Makasar (selanjutnya disebut Bugis) dan puri menjadi akrab. Apalagi Daeng Nachoda dan penembak-penembak meriam Bugis, menjadi tulang punggung kekuatan Jembrana, terutama ketika I Gusti Ngurah Panji Sakti (1680), Raja Den Bukit yang berasal dari utara Pulau Bali (Singaraja-Buleleng) menyerang Jembrana. Jembrana memang kalah, dan menjadi kerajaan vassal Buleleng, namun dukungan kaum Muslim ini tidak pernah pudar, bahkan tetap tertancap kuat dalam benak keluarga puri.

Pada tahun 1799, datang juga iringiringan perahu pimpinan Syarif Abdullah Al-Qadri (syarif tua) yang tak lain adik dari Sultan Pontianak, Syarif Abdurrahman Al-Qadry. Kala itu, Sultan Pontianak takluk dari Belanda (1799). Dan Syarif Abdullah Al-Qadry, tidak terima akan realitas terebut, maka ia meneruskan perlawanan di lautan serta berpetualang dengan membawa eskadron bersenjata meriam. Satu perahu menetap di Lombok Timur, sisanya sampai di Air Kuning Jembrana. Ketika menyusuri 


\section{Pendidikan Karakter Berbasis...}

sungai Ijo Gading ke utara menuju shah bandar, Syarif Abdullah Al-Qadri memberi aba-aba pada anak buah dengan bahasa Kalimantan, Liloan (tikungan), sehingga kampung di sekitarnya lantas diberi nama Loloan hingga sekarang.

$$
\text { Syarif Abdullah Al-Qadri }
$$
mengadakan kesepakatan dengan umat Islam di Jembrana-jika berdasarkan aturan kerajaan, seluruh meriam sebenarnya harus diserahkan ke raja seperti telah dilakukan kaum Bugis yang telah datang lebih dulu setelah perang Makasar-Tetapi Syarif Abdullah Al-Qadry, menawarkan cara lain, yakni meriam tetap dikuasai sendiri, tetapi akan digunakan untuk membela Kerajaan Jembrana. Kesepakatan ini pun dicapai dan kaum Islam asal Kalimantan ini dipersilahkan tinggal di kanan kiri tebing sungai Ijo Gading seluas 80 hektar di sebelah utara Bandar Pancoran.

Syarif Abdullah Al-Qadri membuat perkampungan di sebelah timur sungai yang kini disebut Loloan Timur. Di tempat baru ini, Syarif Abdullah AlQadry yang kemudian dikenal dengan nama Syarif Tua, menjadi pemimpin spiritual, di dampingi oleh Mahbubah (penghulu), Abdul Hamid (khatib), Amsyik (perbekel), dan Tahal (panglima pasukan). Kapal-kapal perang yang mereka miliki kemudian diubah menjadi kapal perniagaan, bahkan pernah menjelajah sampai ke Singapura.

Dua ekspedisi (Bugis dan Pontianak) diatas, merupakan gelombang kedua kedatangan Islam di Jembrana. Kedatangan dua kelompok Muslim ini disambut baik Raja Jembrana. Ada beberapa alasan mendasar kenapa dua kelompok umat Islam ini diterima dengan tangan terbuka: Pertama, eksistensi umat Islam di Jembrana yang telah ada ternyata mampu menjalin hubungan baik dengan komunitas Hindu; Kedua, umat Islam yang telah ada di Jembrana terbukti mampu menjadi tenaga pasukan atau prajurit yang sangat diandalkan serta memiliki loyalitas tinggi. Terbukti ketika Puri Jembrana hancur dan keluarga raja mati dihantam oleh banjir bandang, komunitas Islam tidak sertamerta membangun sebuah kerajaan sendiri. Mereka bahkan membantu pembangunan puri baru yang dibantu oleh Raja Mengwi; Ketiga, realitas menceritakan, bahwa umat Islam memiliki jasa luar biasa dalam pengembangan pelabuhan perniagaan yang memiliki pengaruh sangat positif bagi kemajuan kerajaan; Keempat, kala itu Blambangan telah dikuasai Belanda, sehingga dapat mengancam pula keamanan bahkan masa depan Jembrana. Walhasil, kehadiran para 
pelarian asal Sulawesi dan Kalimantan yang semuanya bekas pasukan kerajaan tentunya dapat menambah kekuatan kerajaan.

\section{Penanaman Karakter melalui Tradisi Male}

Terdapat sebuah kaitan yang erat antara budaya dan tradisi yang berkembang di tengah masyarakat Jembrana sebagai solusi pengokohan kerukunan umat beragama, salah satunya adalah tradisi male. Tradisi male berasal dari tradisi umat Islam di Jembrana. Sekalipun tradisi male merupakan tradisi yang berasal dari Islam, namun dalam pelaksanaannya selalu melibatkan umat Hindu. Perbedaan agama tidak menjadi penghalang dalam pelaksanaan tradisi ini, karena memang umat Islam di Jembrana sangat terbuka terhadap keanekaragaman. Meminjam istilah dari Azyumardi Azra, umat Islam Jembrana bisa dikatakan sebagai "Islam with a smiling face" yaitu Islam yang penuh damai, moderat, sehingga tidak ada masalah dengan modernitas, demokrasi, HAM, perbedaan-perbedaan agama, budaya, dan kecenderungan-kecenderungan lain di dunia modern. ${ }^{31}$

31 Azyumardi Azra, (2003). "Bali and Southeast Asian Islam: Debunking the Myths" dalam Kumar Ramakrishna dan See Seng Tan, eds., After Bali: The Threat of Terrorism in Southeast Asia, Singapore: World Scientific Publishing Co. Pte. Ltd, hlm. 45.
Tradisi Male merupakan bentuk ritual keagamaan yang dilakukan oleh setiap keluarga dan masyarakat Muslim di Jembrana, yaitu ketika masyarakat Muslim Jembrana memperingati Maulid Nabi Muhammad S.A.W. Maulid Nabi dan male merupakan satu kesatuan yang tidak dapat dipisahkan dalam aktivitas ritual-nya bagi masyarakat Jembrana. Male adalah telur yang direbus dengan tidak mengupas (menghilangkan kulit luar) yang dirangkai sedemikian rupa dalam berbagai bentuk yang memiliki nilai estetika dan filosofi keagamaan yang tinggi. Bentuk male ada yang berupa "pajegan" atau bentuk lainnya dengan menusukkan puluhan telur rebus ke batang pohon pisang yang dihiasi kertas warna warni, ada juga yang menyerupai kapal-kapalan, pepohonan (bonsai), dan binatang unta. Rangkaian atau bentuk telur ini, oleh masyarakat Muslim Jembrana disebut dengan male. Male juga biasanya dijadikan bingkisan (berkat) bagi umat maupun undangan yang hadir. Apalagi dalam keluarga itu ada kelahiran, maka dalam "menyelamati" bayi yang baru lahir tersebut wajib menghadirkan male sebagai ucapan syukur kepada Allah S.W.T.

Ritual ini dimulai dengan berkeliling kampung sambil membawa telur yang 


\section{Pendidikan Karakter Berbasis...}

telah dibentuk dengan berbagai corak atau sesuai dengan selera yang diinginkan pembuatnya seperti pura, perahu, masjid, rumah, bonsai dan lainlain. Male yang di-arak mengelilingi kampung ini dikawal oleh pasukan khusus dengan menggunakan pakaian adat Bali yang di sebut pager uyung (pakaian kaum kesatria adat yang diwakili oleh beberapa orang dari umat Islam maupun Hindu). Dalam perjalanannya mengelilingi kampung, male yang di-arak diringi dengan pembacaan asrakal, yaitu membaca solawat serta puji-pujian kepada Nabi Muhammad S.A.W. sambil menabuh rebana atau marawis.

Setelah selesai mengelilingi kampung, kemudian seluruh male atau telur yang telah dihiasi tersebut, dikumpulkan di dalam masjid sambil diiringi bacaan solawat. Telur yang dihiasi dan diwarnai, lalu ditusuk bambu kemudian ditancapkan ke pohon pisang sehinga terlihat pohon pisang berbuah telur (pajegan) yang dipajang saat maulid. Setelah seluruh male dipajang, para jamaah bersenandung solawat secara berjamaah dilanjutkan dengan membaca syair solawat diba' yang berisi tentang sejarah hidup Nabi Muhammad S.A.W. sebagai tanda pengungkapan rasa cinta mereka kepada Nabi Muhammad S.A.W. ${ }^{32}$

Selanjutnya pembacaan doa menjadi acara penutup sebelum telur-telur dibagikan kepada masyarakat yang hadir di sana. Ketika telur dibagikan masyarakat sangat antusias untuk mendapatkan male, walau harus berdesak-desakan dan berebut, mereka percaya bahwa mereka akan mendapat berkah serta keselamatan dari male yang telah didoakan oleh para ulama atau rohaniawan tadi. ${ }^{33}$

Tradisi memperingati maulid Nabi Muhammad S.A.W. dengan male, menjadi sebuah tradisi di Jembrana yang sudah berlangsung selama berabad-abad yang memiliki makna-makna edukatiffilosofis seperti dijelaskan dibawah ini:

Pertama, telur yang sudah direbus dan diwarnai diletakkan di tempat (ember) plastik atau bakul kemudian ditutup daun pisang, sebagiannya lagi ditancapkan di batang pohon pisang. Tradisi ini merupakan sarana implementasi pendidikan informal dari sisi sosial-kebudayaan, yang hakikatnya mengandung makna-makna filosofis. Analogi-nya adalah "ayam berasal dari

32 Dalam sebuah hadits disebutkan, "siapa yang mencintaiku, maka dia bersamaku kelak di Surga”. (H.R. Al-Turmuzi).

M. Abdul Karim, (2016). "Toleransi Umat Beragama di Desa Loloan, Jembrana, Bali” Analisis, XVI, No.1, hlm. 1-30. 
telur dan telur berasal dari ayam". Analogi ini bermakna bahwa telur mengingatkan setiap manusia kalau hidup itu ada awal dan akhir. Jika dilihat dari bentuknya, telur terdiri atas tiga fase, meliputi kulit telur, putih telur, dan kuning telur. Jika dihubungkan dengan kehidupan manusia, fase kulit telur dimaknai sebagai lahir, fase putih telur sebagai hidup, dan fase terakhir yaitu kuning telur sebagai akhir kehidupan.

Dengan nada yang secara eksplisit serupa, Rifqil Halim, ${ }^{34}$ menjelaskan, bahwa kulit telur merupakan simbol Iman, putih telur simbol Islam, dan kuning telur merupakan simbol Ihsan. Putih telur juga melambangkan kesucian dan keagungan, sementara kuning telur melambangkan keemasan, dan warnawarna lain seperti merah dan biru yang mewarnai kulit telur saat maulid sebagai lambang kegembiraan. Jadi telur yang ditusuk saat maulid melambangkan bahwa Iman, Islam, dan Ihsan, harus disatukan dan ditegakkan ke atas berdasarkan kalimat tauhid "la ilaha illallah Muhammad rasul allah". Telur yang ditusuk bambu melambangkan adanya kelurusan, kekuatan, dan keteguhan, layaknya pohon bambu yang tumbuh menjulang tinggi. Walhasil, berangkat dari tradisi male pada maulid

\footnotetext{
${ }^{34}$ Wawancara dengan Rifqil Halim, tanggal 4 Agustus 2018.
}

Nabi Muhammad S.A.W. diharapkan menanamkan karakter bagi Muslim Jembrana untuk selalu tegak, lurus, dan konsisten dalam meneladani akhlak Nabi Muhammad S.A.W. sebagai manusia termulia dan paling berbudi luhur.

Kedua, pohon pisang yang padanya ditancapkan telur saat maulid juga memiliki makna filosofi. Allah S.W.T. berfirman "Kami keluarkan dari tanaman yang menghijau itu butir yang banyak maka perhatikanlah buahnya di waktu pohonnya berbuah dan (perhatikan pula) kematangannya". Al-Qur'an kemudian menyebutkan bahwa pisang sebagai salah satu buah-buahan surga berada di antara pohon bidara yang tidak berduri dan pohon-pohon pisang yang bersusunsusun buahnya. (QS. 56: 28-29). ${ }^{35}$ Firman ini yang menggambarkan bahwa pohon pisang dan buahnya harus dijadikan ibrah, karena memiliki khasiat dan kegunaan yang banyak. Buah pisang dapat menyehatkan usus dengan menghilangkan sembelit, selanjutnya daun pisang dapat digunakan sebagai alas, penutup, dan atau pembungkus makanan atau juga bisa dipakai sebagai payung. Daun pisang yang sudah digunakan dan mengering atau tangkai

\footnotetext{
35 Q.S. [56]: 28-29.

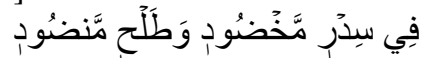

"Berada di antara' pohon bidara yang tak berduri, dan pohon pisang yang bersusun-susun
} (buahnya)." 


\section{Pendidikan Karakter Berbasis...}

daun yang sudah kering dapat pula dimanfaatkan manusia sebagai bahan bakar atau simbol pemicu bagi bahan bakar kayu yang lebih kuat. Ini bermakna pemberi semangat bagi manusia untuk menjalani kehidupan seperti yang dialami oleh Nabi Muhammad S.A.W.

Ketiga, batang pisang yang dipenuhi serat-serat yang panjang dapat dimanfaatkan manusia untuk tali-temali yang dipintal, sebagian lagi digunakan sebagai pita-pita untuk bahan anyaman, juga dapat digunakan sebagai bendabenda pakai, seperti; tas, dompet, sarung bantal kursi dan lain-lain. Batang pisang yang sudah lapuk dapat dimanfaatkan sebagai penyubur tanah pertanian. Ini semua menggambarkan agar melalui tradisi male, manusia mampu menjadikan dirinya bermanfaat untuk sesamanya dan untuk makhluk lain. Pohon pisang tidak mau mati sebelum melahirkan tunastunasnya, artinya pohon pisang memberikan gambaran yang baik mengenai alih generasi, begitu pula jika dikontekstualisasikan dalam pergantian kepemimpinan (suksesi), maka pohon pisang telah mengajarkan kepada manusia agar menyiapkan kaderisasi sebagai bentuk regenerasi.

Keempat, Setandan buah pisang jika diperhatikan ternyata bergantung pada ares yang berada di dalam pohon pisang.
Jadi ares tersebut identik dengan isi pohon pisang. Filosofi pisang dari kacamata tafsir spiritual, ares mengisyaratkan sebagai Arsy (singgasana Allah S.W.T.) yang identik dengan hati atau kalbu seorang Muslim yang bersih dan bening. Dalam makrifat tasawuf, hati orang mukmin yang bening bisa merupakan Arsy-nya, sebab di alam semesta ini tidak ada yang mampu menampung Allah kecuali "bersemayam" dalam bersih dan beningnya hati seorang Mukmin, sebagaimana dikabarkan dalam hadits Qudsi bahwa Allah berfirman, "Bumi dan langit-Ku tidak ada yang mampu menampung Aku, tapi hati hamba-Ku yang berimanlah yang menampung-Ku. ${ }^{36}$ Dari sini dapat dipahami bahwa ares yang bisa menghasilkan buah pisang tempatnya di dalam pohon pisang, berarti untuk mendapatkan ares, maka harus membuka pohon pisangnya, melepas satu per satu kulit pada pohon pisang yang membungkus ares.

Begitu pula dengan hati manusia yang bening harus diupayakan menjadi bersih dan terbebas dari kotoran penyakit-penyakit hati atau sifat-sifat

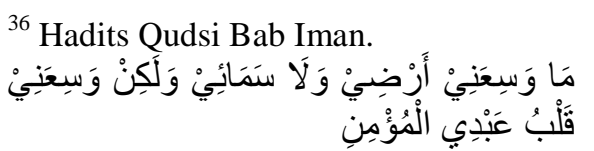

"Tidak dapat menampung-Ku (rahasia keluhuran Allah) bumi-Ku atau langit-Ku, akan tetapi mampu menampung-Ku hati hamba-Ku yang beriman." 
buruk dan hati seperti itulah yang menjadi tajalli-Nya Allah atau tempat bersemayam-Nya. "Hati itu bagaikan Arsy (singgasana-Nya) dan dada adalah kursinya hal itu menunjukkan, bahwa yang dimaksud hati adalah sesuatu dibalik daging sanubari. Selain itu pohon pisang juga mempunyai daun yang bisa dipakai sebagai payung atau perlindungan dari guyuran air hujan dan terik panas matahari, maksudnya adalah manusia harus dapat melindungi dan mengayomi sesama seperti diisyaratkan oleh daun pisang yang dapat melindungi segala kondisi.

Selain memiliki makna-makna edukatif-filosofis, tradisi male sebagaimana diutarakan oleh KH. Ahmad Muzakki, ${ }^{37}$ mengandung nilai-nilai luhur yang dibutuhkan dalam rangka menciptakan kehidupan yang harmonis. Nilai-nilai luhur itu antara lain: nilai etika, estetika, dan nilai sosial. Implementasi dari nilai-nilai tersebut dapat dilihat dari: Pertama, nilai etika. Proses arak-arakan bertujuan untuk memberitahukan kepada khalayak ramai khususnya warga yang beragama Hindu (umat mayoritas), bahwa umat Muslim mohon izin sedang melaksanakan kegiatan peringatan hari besar keagamaan yang dalam perjalanannya

${ }^{37}$ Wawancara dengan KH. Ahmad Muzakki, tanggal 4 Agustus 2018. tidak hanya diikuti oleh umat Muslim, tetapi umat diikuti oleh Hindu, bahkan banyak dari proses arak-arakan dikawal oleh pecalang (polisi adat Bali); Kedua, nilai estetika. Nilai estetika dalam tradisi male dapat dilihat melalui bentuk atau model male itu sendiri yang mengandung nilai seni yang tinggi. Bentuk nilai seni lainnya adalah dalam pembacaan asrakalan pada saat male itu di arak keliling kampung. Dengan menggunakan pakaian hasil akulturasi budaya Islam dan Hindu peserta pawai seolah-olah hanyut ke dalam suasana arak-arakan; Ketiga, nilai sosial. Nilai sosial yang terdapat dalam tradisi male ini adalah sebagai sarana berbagi makanan kepada masyarakat luas, baik mereka yang beragama Islam ataupun mereka yang beragama Hindu.

Uniknya, dalam tradisi ini tidak dibatasi oleh umat Muslim saja, tetapi banyak dari umat Hindu yang mengikuti prosesnya. Telur sebagai bahan utama dari male di bagikan kepada seluruh peserta Maulid Nabi dengan tanpa memandang perbedaan agama. Aktivitas seperti itu adalah bentuk nyata dari tradisi masyarakat Jembrana yang secara sadar bersama-sama untuk hidup rukun dalam keberagamaan. Potret yang terjadi di Jembrana adalah wujud dalam implementasi penanaman pendidikan 


\section{Pendidikan Karakter Berbasis...}

karakter berbasis ethnopedology yang di awali dari dalam keluarga lalu meluas ke tengah masyarakat. Mereka sadar bahwa mereka berbeda dari segi agama, tetapi perbedaan agama bukanlah menjadi sekat atau suatu yang dapat menghalangi untuk hidup rukun bersama-sama dalam membangun peradaban atau menciptakan sebuah masyarakat madani antara umat Islam dan Hindu di Jembrana.

Jika dilihat lebih jauh, sejak masa kelahirannya, agama Islam agama telah mengalami perjumpaan (encounter) dan terlibat secara intends dengan beraneka ragam keyakinan dan agama. Terhadap adanya pluralitas tersebut, Islam memberi prinsip dasar bahwa pluralitas merupakan sunnah Allah. Karenanya, setiap Muslim seharusnya memanfaatkan pluralitas itu sebagai sarana untuk saling mengenal, saling belajar, dan saling berlomba untuk memperoleh kebaikan (fastabiq alkhayrat). Interaksi dan komunikasi dengan kelompok yang berbeda, hendaknya dilakukan dengan penuh penghormatan, menjunjung nilai-nilai kemanusiaan, dan tetap mengembangkan solidaritas kemanusiaan (ukhuwah basyariyyah). ${ }^{38}$

${ }^{38}$ Suprapto, (2011). "Islam, Pluralitas, dan Kerukunan Antar-Agama Perspektif Interdisciplinary Studies", Mimbar, Jurnal Agama dan Budaya, 28, No. 1, hlm. 49-66.

\section{E. KESIMPULAN}

Penelitian menyimpulkan beberapa hal berikut. Pertama, kendati tradisi male pada awalnya merupakan tradisi yang berasal dari umat Islam, tetapi memiliki dampak sosial yang dirasakan juga oleh Hindu yang kemudian umat Islam pun dengan senang hati melakukan aktivitas tradisi male sebagai bentuk dari proses komplementasi antar umat beragama; Kedua, adanya proses pendidikan berbasis kearifan lokal yang dapat ditemukan dalam tradisi male. Hasil dari aktivitas ini adalah terciptanya karakter individu masyarakat Jembrana yang toleran, humanis, dan pluralis antar umat Hindu dan Muslim; Ketiga, adanya kegiatan atau aktivitas masyarakat yang dapat menumbuhkan rasa untuk saling memperhatikan dan memahami sehingga terbangun karakter individu, meliputi pengetahuan (moral knowing), perasaan (moral feeling), dan tindakan (moral action) sebagaimana yang diungkapkan oleh Thomas Lickona.

Dengan terus ditumbuhkembangkannya tradisi male ini, masyarakat Jembrana merasa tidak ada perbedaan dalam berinteraksi sosial. Yang membedakan diantara mereka hanya agama saja. Tetapi melaui aktivitas ini perbedaan agama diantara mereka tidak menjadi jurang pemisah dalam 
berinteraksi dan hidup bersama ditengahtengah masyarakat.

Penelitian merekomendasikan pentingnya memikirkan kembali sebuah model pendidikan karakter berbasis kearifan lokal (ethnopedagoy), setidaknya terkait dengan relasinya antra Muslim dan non-Muslim, bahkan untuk umat beragama di Indonesia secara keseluruhan. Karena, sebenarnya, akar masalah dari konflik sosial bisa jadi disebabkan dari ketidaktahuan setiap individu di masyarakat akan pentingnya manfaat dari model pendidikan karakter yang berbasis kearifan lokal (ethnopedagoy). Manfaat yang dapat diambil dari model pendidikan karakter berbasis kearifan lokal adalah selain menanamkan kembali atau mempertajam pandangan hidup satu masyarakat, melalui model pendidikan seperti ini, maka akan terciptanya subuah proses asosiasi, Integrasi, komplementasi, dan sublimasi yang kuat ditengah-tengah masyarakat yang multikultural.

\section{DAFTAR PUSTAKA}

Azra, A. (2003). "Bali and Southeast Asian Islam: Debunking the Myths" dalam Kumar Ramakrishna dan See Seng Tan, eds., After Bali: The Threat of Terrorism in Southeast Asia, Singapore: World Scientific Publishing Co. Pte. Ltd.

Azra, A. (2003). Pendidikan Multikultural: Membangun Kembali
Indonesia Bhinneka Tunggal Ika. Jakarta: Republika.

Bailey, K. D. (1982). Methods of Social Research. New York: A Division of Macmillan Publishing Co. Inc.

Biklen, R. B. dan S. K. (1998). Qualitative Research for Education: An Introduction to Theory and Methods. Boston: Allyn and Bacon.

Chaer, M. T. (2016). Islam dan Pendidikan Cinta Damai. ISTAWA, 2(1), 73-94.

Damanhuri, A. (1995). Sekilas Pandang Perkembangan Umat Islam di Kabupaten Dati II Jembrana. Jembrana.

Egan, K. (2002). Getting it Wrong from the Beginning Our Progressivist Inheritance from Herbert Spancer, John Dewey, and Jean Peaget. Binghamtom: Vail Ballou.

Guba, Y. S. L. dan E. G. (1985). Naturalistic Inquiry. Newbury Park: SAGE.

Hubermen, M. M. dan M. (1992). Analisis data Kualitatif. Jakarta: Universitas Indonesia.

Idris, S. (2014). Demokrasi dan Filsafat Pendidikan. Banda Aceh: Ar-Raniry Press.

Indagosa, I. B. (2000). Sejarah Terbentuknya Kabupaten Jembrana. Negara.

Islam, A. S. dan M. A. M. (2009). Beberapa Aspek Kodikologi Naskah Keagamaan Islam di Bali. Lektur Keagamaan, 7(1), 53-90.

Karim, M. A. (2016). “Toleransi Umat Beragama di Desa Loloan, Jembrana, Bali” Analisis, XVI, (1), 1-30.

Machali, I. (2013). Peace Education dan Deradikalisasi Agama. Jurnal Pendidikan Islam, 2(1), 41-64. 


\section{Pendidikan Karakter Berbasis...}

https://doi.org/10.14421/jpi.2013.21. 41-64

Mashad, D. (2014). "Muslim Bali", Mencari Kembali Harmoni yang hilang. Jakarta: Pustaka Al-Kautsar.

Meredith D. Gall, Joyce P. Gall, dan W. R. B. (2003). Educational Research: An Introduction, 7th eds. Boston: Pearson Education, Inc.

Merriam, S. B. (2009). Qualitative Research: A Guide to Design and Implementation (USA). The JosseyBass.

Mulyana, D. (2002). Metodologi Penelitian Kualitatif: Paradigma Baru Ilmu Komunikasi dan Ilmu Sosial Lainnya. Bandung: Remaja Rosdakarya.

Saidi, S. (2002). Sejarah Keberadaan Umat Islam di Bali. Denpasar.

Saputra, R. R. H. (2016). Berfikir Supra Rasional. Jakarta: Republika.

Stetsenko, A. (2011). From relational ontology to transformative activist stance on development and learning: expanding Vygotsky's (CHAT) project. Springer, 6(7), 471-491. https://doi.org/10.1007/s11422-0089111-3.

Sumarsono. (1990). Pemerintahan Bahasa Melayu Loloan di Bali. Universitas Indonesia.
Sumiati, D. (2017). Intercultural Communication Based on Local Wisdom That Made the People of Bali Reject Sharia Tourism. Asian Journal of Media and Communication, 1(2), 137-146.

Suprapto, (2011). "Islam, Pluralitas, dan Kerukunan Antar-Agama Perspektif Interdisciplinary Studies", Mimbar, Jurnal Agama dan Budaya, 28, (1), 49-66.

Syam, M. N. (1984). Filsafat pendidikan dan dasar filsafat pendidikan pancasila. Surabaya: Usaha Nasional.

Varshney, A. (2002). Ethnic Conflict and civic life: Hindu and Muslim in India. New Haven and London: Yale University Press.

\section{Wawancara}

Wawancara dengan Asmari, tanggal 7 April 2018.

Wawancara dengan KH. Ahmad Muzakki, tanggal 4 Agustus 2018.

Wawancara dengan Ida Bagus Komang Santika Putra, tanggal 7 April 2018.

Wawancara dengan Rifqil Halim, tanggal 4 Agustus 2018. 